UDC 378:37.02:37.01/.09

\author{
Oksana M. Sovhar \\ PhD of Pedagogical Sciences, Associate Professor of Foreign Languages and Military Translation Department \\ Hetman Petro Sahaidachnyi National Army Academy, Lviv, Ukraine \\ ORCID ID 0000-0002-3101-7409 \\ okssov@yahoo.com
}

\title{
USING ICT TO FORM FOREIGN LANGUAGE COMMUNICATIVE COMPETENCE OF FUTURE ARMED FORCES OFFICERS
}

\begin{abstract}
The article provides an analysis, theoretical justification and results of empirical approbation of using information and communication technologies as a tool to help future officers of the Ukrainian Armed Forces acquire foreign language communicative competence. A broad overview of the ICT employed in language teaching has been provided, as well as the rationale behind integrating ICT into cadets' language learning process. In order to validate the effectiveness of ICT in military learning environment, a pedagogical experiment has been conducted; its findings have been described. It has proved the efficiency of using ICT in the process of language learning in a military higher education institution, resulting in the increase in cadets' language proficiency, professional preparedness, and overall academic skills. Implementation of ICT was also instrumental in providing powerful motivation, having an effect on cadets' attitude towards language learning and promoting their autonomy, creativeness and cognitive skills. Future officers found the ability to interact and maintain real-life contact with native speakers, counterparts or military experts and engagement in international projects through video chats and video calls to be a particularly inspiring and enjoyable experience. Another benefit of integrating ICT is the opportunity to present subject matter in different ways depending on the cadets' individual learning style. Using visual aids such as pictures, videos, multimedia presentations, infographics, etc. motivated cadets to be engaged in reading, making texts easier for comprehension when illustrated with pictures, graphics, illustrations, audio and video. The technology gave the cadets a greater control over their learning progress and more freedom to collaborate in the classroom.
\end{abstract}

Keywords: information and communication technology (ICT); cadets; foreign language communicative competence; language learning.

\section{INTRODUCTION}

Problem statement. The strategy of integration into the European and global military community chosen by the Ukrainian state actualizes the problem of interoperability of the Ukrainian army with the armed forces of other countries, which, in turn, leads to the necessity to increase the level of foreign language competence of Ukraine's military personnel. Currently, effective foreign language learning is impossible without the use of information and communication technologies (ICT), as they provide access to broad educational information resources in order to improve foreign language communication skills, update critical and creative thinking, engage cadets in a wide range of communicative tasks, and raise their motivation and language awareness. The efficacy of incorporating innovative methods of teaching/learning English with the use of ICT is extending the opportunities for cadets to acquire communicative competence practising English with real people and in real contexts; which is achievable by encouraging and leading them to use technology to their advantage.

Selecting proper and efficient teaching methods, forms, strategies and techniques is a key to future officers' acquisition of effective communicative competence. Technology has a great impact on teaching English, as it makes teachers rethink what they are doing and expand 
the number of teaching approaches to diversify learning process and make it more productive. The use of ICT can make the learning environment flexible, interactive, and innovative.

Analysis of recent research and publications. Various aspects of using ICT in language teaching/learning have been of interest to a great number of foreign scholars, namely S. Ammanni, C. Chapelle, N. Garret, M. Lin, M. Lubis, M. Melor, and S. Young as well as Ukrainian researchers, among them N. Bibik, T. Kolodko, S. Petrushina, T. Symonenko, O. Volchenko, Y. Vtornikova, etc. The structure of student communicative competence was substantiated by A. P. Elisafny, J. Habermas, D. Hymes, T.Xiao and others. $S$. Hennessy et al. focused on the specifics of the use of ICT in subject teaching [1]. M. Yunus et al. have tackled advantages and disadvantages of using ICT in teaching English [2]. V. Bykov studied the role of information technology learning in the individualization of the educational process [3]. R. Gurevych et al. have examined Google classroom as an effective tool in vocational schools [4]. M. Zhaldak's scientific research is devoted to the informatization of education and its globalization, as well as the problems of creating and implementing computer-based teaching aids [5]. I. Klak and N. Yatseniuk [6] analysed the use of multimedia teaching technologies in forming prospective language teachers' communicative competence. A.Yurzhenko devoted her research to the description and analysis of the work of the future maritime specialists in an e-course [7]. However, despite their prevalence and undeniable value in the educational process, modern information and communication technologies have not yet been sufficiently incorporated in foreign language learning programs for future officers of the Armed Forces of Ukraine.

The purpose of this study is to research the effectiveness of using ICT in language training in order to form communicative competence of Army cadets. In accordance with the purpose of the study, the tasks were set to analyze the didactic potential of ICT, outline the specificity of using ICT in the formation of cadets' foreign language communicative competence, determine the criteria, indicators and levels of formation of this competence.

\section{THE THEORETICAL BACKGROUNDS}

"The immense development of information technologies causes big changes also in education process", claim S. Hubackova and M. Ruzickova [8]. According to the definition by Asabere and Enguah [9], ICT are the facilities, tools, equipments, and processes which provide the needed environment with the infrastructure and services for the accumulation, processing, storing, transmission, and dissemination of information including text, voice, data, video, and graphics. Among the ICT are interactive whiteboards, computers, office applications (Word, PowerPoint, drawing tools etc.), computer assisted language learning (CALL) and Language Management Systems (LMS) software, the Internet - websites and downloadable software, course book CD-ROMs, DVD players, mobile phones, electronic dictionaries, digital cameras and videos, DAT recorders, document cameras, data projectors. In a similar vein Livingstone [10] states that ICT include technologies specific to the learning environment (e.g. interactive whiteboards) and networked technologies. Hennessy et al. [1] argue that the term ICT encompasses a range of hardware (desktop and portable computers, projection technology, digital recording equipment, data logging), software (generic software, multimedia resources), and means of telecommunication and information systems (Intranet, Internet). ICT refer to technological tools and resources which are employed to communicate, create, disseminate and manage information [10]. D. Çakici believes that "the increase of information and communication technologies has dramatically reinforced and created powerful learning atmosphere" [11]. Without doubt, ICT are seen as essential in language training for the military, since they can be incorporated at various stages of the educational process, ensuring an individual approach (starting from diagnostic testing and all the way up 
to individual tasks cadets have to accomplish on computers during their graduation exams), increasing cadets' motivation to improve their communicative and language competence through the use of various software and Internet resources, providing continuous assessment of cadets' level of communicative skills and abilities, and monitoring their progress by means of various information assets, making language environment innovative, flexible, and interactive. Among the vast array of ICT, multimedia technologies and educational software are perhaps the most popular and widely used in the language classroom today. We cannot but share the opinion of I. A. Vereitina [12], who states that in order to be instrumental in forming foreign language competence, ICT are to be used in a specific educational environment which has to:

- ensure interactive forms of learning;

- be artificially created to provide computer-integrated environment;

- provide didactic support of virtually delivered knowledge;

- eliminate learners' physiological resistance to learning in virtual environment;

- encourage learners' individual studies in virtual domain.

The evolution of the term "communicative competence" starts with D. Hymes [13], who defined it as an aspect of one's competence which enables the person to negotiate meanings interpersonally within specific contexts. Focus is put on the ability to communicate functionally and interactively in a language. Acquiring communicative competence involves formation of a certain set of language skills, namely: ability to clearly and coherently express oneself in a foreign language; ability to describe some current, past, future or hypothetical situation, rendering related emotions and feelings, plans and expectations; ability to speak fluently and spontaneously, without a tangible need to choose words in a foreign language; ability to effectively use a foreign language in social communications and perspective professional activities, ability to find, accumulate, store, transmit, change, and disseminate information in a foreign language with the help of information and communication tools; ability to express oneself comprehensively, in detail and logically by means of various syntactic means; ability to mediate in a foreign language; and the ability to carry out correct translation of professionally oriented texts. Future officers of the Armed Forces of Ukraine in the process of their language learning are expected to form communicative competence which is a synergy of communicative knowledge, skills and abilities. To achieve this, teachers need to wisely select or develop a set of activities that can be implemented using information and communication technologies to enhance receptive (listening, reading, audiovisual perception) and productive (speaking and writing) domains of language competence.

\section{RESEARCH METHODS}

The study involved a set of research methods that meet its goals and objectives, namely: theoretical: the analysis of philosophical, sociological, psychological, pedagogical, historical, and methodological resources to substantiate the theoretical and methodological foundations of the problem under study; systematization and generalization of the experience of using modern ICT in the process of language teaching/learning; abstraction, idealization, logicalstructural analysis of the researched problem; empirical: pedagogical experiment to identify the effectiveness of the use of ICT in formation of communicative competence of future defense professionals; questionnaire, survey, testing, analysis of cadets' performance of creative tasks to determine the level of indicators of communicative competence; expert assessment of forms, methods, means of formation of communicative competence of future officers and the role of ICT in the process of language training; statistical: methods of 
mathematical statistics to verify the reliability and significance of the results of the conducted experiment (Fisher's angular transformation criterion).

\section{FINDINGS}

Experimental basis of the research. The experiment was carried out at the Hetman Petro Sahaidachnyi National Army Academy with the participation of 237 cadets studying for a bachelor's degree in the speciality "Combat employment of mechanized units", of which 115 were experimental group, 122 were control group. At the summative stage of the experiment, the homogeneity of the selected control and experimental groups according to the distribution of the level of formation of foreign language communicative competence was confirmed.

For our experiment we formed key (reference) criteria and relevant indicators of the effectiveness of the process of language training of future military professionals, based on results of the research carried out by American scholars B. Shpitsberg and V. Cupach [14], who specify that motivation, knowledge and skills are the main components of communicative competence. We singled out (Table 1): cognitive criterion - the amount and quality of language knowledge; understanding the essence and content of terminology; ability to synthesize, analyze, generalize, structure and produce; motivational criterion - the presence of cognitive interests and cognitive and communicative needs in the chosen field; the presence of internal motives for personal and professional growth; desire for selfimprovement; activity criterion - the formation of language skills; development of oral and written speech; ability to render practical experience in the specialty; professional creativity and activity. The criteria with their relevant indicators are presented in Table 1.

Table 1

\section{Criteria of communicative competence and their indicators}

\begin{tabular}{|c|c|}
\hline Criterion of communicative competence & Indicator of communicative competence \\
\hline Motivational & $\begin{array}{l}\text { Focus on obtaining the deepest possible knowledge } \\
\text { and skills in a foreign language } \\
\text { Ability to work with discourse from various sources } \\
\text { Skills to find and categorize information using ICT } \\
\text { Ability to justify one's own opinion } \\
\text { Tolerant attitude towards other cultures } \\
\text { Ability to analyze one's activities } \\
\text { Ability for self-esteem } \\
\text { Ability to be communicative }\end{array}$ \\
\hline Cognitive & $\begin{array}{l}\text { Knowledge and skills in spelling, morphology, syntax, } \\
\text { and vocabulary } \\
\text { Knowledge of language norms of discourse structure } \\
\text { Grammatical and lexical correctness } \\
\text { Coherent and fluent speech } \\
\text { Ability to perform tasks orally and in writing } \\
\text { Ability to work with modern information and } \\
\text { communication technologies } \\
\text { Ability to retell a text in one's own words and } \\
\text { highlight the main idea } \\
\text { Ability to work with scientific literature, including } \\
\text { electronic resources } \\
\text { Ability to understand what is read and heard } \\
\text { Ability to summarize information from various } \\
\text { sources, including virtual ones }\end{array}$ \\
\hline Activity & $\begin{array}{l}\text { Ability to formulate, express and justify one's own } \\
\text { opinion } \\
\text { Ability to render the gist of a message }\end{array}$ \\
\hline
\end{tabular}




\begin{tabular}{|l|l|}
\hline & Ability to use foreign language in social, professional \\
& life, and in learning process \\
Ability to speak in public \\
Ability to use subject knowledge \\
Ability to report on one's educational and professional \\
activities \\
Ability to distribute and organize work among others \\
Ability to cooperate and collaborate \\
Ability to prevent and resolve conflict situations \\
Ability to show empathy \\
Ability to prepare reports on work performed \\
Ability to present one's own research and results of \\
professional activities
\end{tabular}

To determine the level of formation of communicative competence of future officers of the Armed Forces by means of ICT, we used the selected criteria, indicators and the designed scale. Namely, the general level of formation of communicative competence $\left(L_{c c}\right)$ will be considered by us as an integral indicator of diagnostics of separate criteria and indicators:

$$
L c c=\sum_{i=1}^{3} C_{i},
$$

where $C_{i}$ is the criteria of formation of communicative competence of future officers of the Armed Forces by means of ICT presented in Table 1:

$$
C_{i}=\sum_{j=1}^{3} I j / 3
$$

The adoption of a 3-point scale in assessing the level of communicative competence of future officers of the Armed Forces and correlating the level of foreign language proficiency with the European approach determined our choice of a three-level scale for evaluating the results of the experiment: creative, constructive and reproductive levels of communicative competence $\left(L_{c c}\right)$. The creative level of formation of communicative competence of future officers of the Armed Forces by means of ICT is characterized by the results of diagnostics $0.7<L_{c c}<1$ and, accordingly, a high level of manifestation of selected criteria and indicators. Namely, cadets with a creative level of communicative competence are characterized by conscious motivation for the development of communicative competence and professional growth; high level of language knowledge, formation of socio-cultural and communicative skills, high level of autonomy, creativity and technological skills in accomplishing educational language tasks; understanding the role of ICT in the language activities of future officers and the ability to use ICT to achieve personal, educational and professional goals. The constructive level of formation of communicative competence of future officers of the Armed Forces by means of ICT was yielded by diagnostics results as $0.4<L_{c c}<0.7$, which, in turn, is due to the uneven manifestation of certain criteria and indicators of experimental research. Thus, this level encompasses cadets who have a high level of social and communicative skills as psychological communication abilities, but cannot support them with strong professional knowledge, because they do not have a conscious intrinsic motivation to master the profession. On the other hand, it may also include cadets with high performance, who, at the same time, do not manifest initiative, autonomy, creativity and ability to solve technological problems. That is, working with such cadets, teachers should pay attention to those indicators which reduce the general level of communicative competence, and try to decrease or eliminate them. The reproductive level is characterized by a quantitative assessment of $0<L_{c c}<0.4$. Here, cadets show insufficient level of autonomy, creativity, 
technological and social communication skills. Future officers with a reproductive level do not know how to use ICT to tackle professional and educational problems. Teachers' efforts here should be aimed at forming basic attitudes, knowledge and skills regarding communicative competence and the role of ICT for personal and professional development of future officers.

The following stages of organizing the experimental research on the formation of communicative competence of future officers by means of ICT were carried out: 1) organizational stage: based on the results of analysis of resources on the essence, content and structure of communicative competence, we identified criteria, indicators and levels of communicative competence of future officers, selected diagnostic tools that would meet the selected criteria; 2) summative stage: we determined the current state of formation of communicative competence of cadets participating in the experiment, with the support of selected tools and characterized the existing tendencies of applying ICT in the language training of future officers; 3) formative stage: we incorporated various ICT into the process of language training of future officers in the experimental group; 4) final stage: we assessed the level of effectiveness of the implemented innovations by comparing the results of re-diagnosis of cadets from control and experimental groups, and drew conclusions about the levels of communicative competence of the experiment participants in traditional and modified learning environments.

Methods for diagnosing the communicative competence formation by means of ICT are presented in Table 2.

Table 2

Methods for diagnosing the formation of communicative competence by means of ICT

\begin{tabular}{|c|c|c|c|}
\hline & Indicators & Diagnostic method & Diagnostic tasks \\
\hline \multirow{3}{*}{$\mathrm{C}_{1}$} & $\mathrm{I}_{\mathrm{m}}$ (motivational) & $\begin{array}{l}\text { Questionnaire "Motivational- } \\
\text { stimulating component in the } \\
\text { formation of communicative } \\
\text { competence" }\end{array}$ & $\begin{array}{l}\text { To determine the level and nature } \\
\text { of motivation of future officers to } \\
\text { form communicative competence }\end{array}$ \\
\hline & $\mathrm{I}_{\mathrm{c}}$ (cognitive) & $\begin{array}{l}\text { Indicator method to assess cadets' } \\
\text { communicative competence }\end{array}$ & $\begin{array}{l}\text { To assess the level of cadets' } \\
\text { lexical, sociocultural, research, } \\
\text { organizational and reflective } \\
\text { abilities }\end{array}$ \\
\hline & $\mathrm{I}_{\mathrm{a}}$ (activity) & $\begin{array}{l}\text { Survey on social communication } \\
\text { competence }\end{array}$ & $\begin{array}{l}\text { To study the manifestation of } \\
\text { cadets' personal characteristics } \\
\text { that determine the level of } \\
\text { success in communication }\end{array}$ \\
\hline \multirow[t]{3}{*}{$\mathrm{C}_{2}$} & $\mathrm{I}_{\mathrm{u}}$ (autonomy) & \multirow{3}{*}{$\begin{array}{l}\text { Analysis of cadets' performance } \\
\text { in completing creative tasks }\end{array}$} & $\begin{array}{l}\text { To assess the level of cadets' } \\
\text { autonomy and cognitive activity } \\
\text { in the process of solving training } \\
\text { tasks }\end{array}$ \\
\hline & $\mathrm{I}_{\mathrm{r}}$ (creativity) & & $\begin{array}{l}\text { To examine cadets' educational } \\
\text { and professional creativity }\end{array}$ \\
\hline & $\mathrm{I}_{\mathrm{p}}($ performance $)$ & & $\begin{array}{l}\text { To determine the level of cadets' } \\
\text { technological knowledge and } \\
\text { skills }\end{array}$ \\
\hline \multirow{3}{*}{$\mathrm{C}_{3}$} & $\mathrm{I}_{\mathrm{f}}$ (forms, methods) & \multirow{3}{*}{$\begin{array}{l}\text { Survey on the role of ICT in the } \\
\text { future officers' language training }\end{array}$} & $\begin{array}{l}\text { To assess the effectiveness of } \\
\text { forms and methods of teaching/ } \\
\text { learning using ICT }\end{array}$ \\
\hline & $\mathrm{I}_{\mathrm{n}}$ (means) & & $\begin{array}{l}\text { To describe ICT as means for } \\
\text { future officers' language training }\end{array}$ \\
\hline & $\mathrm{I}_{\mathrm{i}}$ (innovations) & & $\begin{array}{l}\text { To investigate the nature of } \\
\text { innovations in the use of ICT }\end{array}$ \\
\hline
\end{tabular}


The application of computer technologies in language classroom fostered cadet-centred learning, gave teachers the possibility to diversify lesson styles, motivated cadets with different interests and learning styles, provided learning opportunities outside the classroom, and catered more for individual differences. Flipped classroom was introduced, where input was being learned or read during self-study and later discussed and explored further in the classroom. Another methodology, involving ICT, was that of blended learning enhanced by a technology to cover areas of the curriculum not covered in the classroom.

The classes integrating ICT were conducted to develop receptive and productive domains of language skills in and outside the classroom and included exploiting the Internet ready-made exercises and tests, accessing media sites to develop language skills, interacting with native and non-native speakers via e-mails, social networks, blogs and other Web 2.0 applications; doing online courses; using online reference tools, e.g. online dictionaries; thesauri, grammar, spelling and pronunciation checkers, encyclopedias, online writing labs and creating and publishing one's work.

ICT were used to the advantage of practising writing through plethora of different mediums, like e-mails, blogs, social networks, wikis, online forums, and discussion boards. First of all, having cadets complete their writing assignments on computers made everyone's life easier. Composing on computers ensured that the pieces of writing were neat and well arranged; the problem of handwriting legibility was eliminated. Moreover, it saved the time of editing and providing citations from different sources to enrich the final product. The undeniable benefit of composing on computers was the possibility of online publishing, provided by the Internet. This way not only the teacher would read and provide feedback but people from all over the world, which was a motivating factor for cadets and encouraged them to take extra effort to make their writings better. An added value was having graphs images, drawings, hyperlinks, and video added to cadets' text, making it more interesting and comprehensible.

Speaking was assisted by technology in two modes, tutorial Computer-Assisted Language Learning (CALL) and Computer-Mediated Communication (CMC). Tutorial CALL practice was used to facilitate memory storage of phonemic and morphological contrasts as well as assist in lexical phrase retrieval. CALL programs that presented electronic flash cards were employed for cadets to subvocalize when they were learning new words and phrases. With these programs cadets could compare their own audio recordings with those of native speakers with diverse accents and receive feedback in a form of automatic speech recognition. Cadets also had to carry out specific tasks, such as individual sound practice, word recognition, or short sentence repetition. Dictation exercises were completed online via the Dragon software or other programs such as Online Dictation, Evernote, TalkTyper, VoiceAssistant, Speechlogger, or PaperPort. When using the Dragon app cadets received transcriptions into the foreign language - the best guess as to what the cadet actually said and if the transcription contained errors, the cadet knew that the pronunciation had deviated. Using the online program VoiceThread, cadets created collaborative online stories illustrated with sound, images, and text. Then VoiceThread slides were posted online, giving others opportunity to address, add comments or answer questions posed by the authors, thereby enriching the entire project. Learning manage systems (LMSs) were used to make video postings using a Flash plugin. Teachers used this type of digital tool to allow students to post their best video recording through the LMS platform, which afforded them more planning time, thereby enhancing accuracy, increasing linguistic complexity, and fostering fluency. Another tool widely used during the experimental work was videoconferencing, based mostly on the platforms of Adobe Connect, Big Blue Button, Microsoft Teams, Skype, Google Hangout, and Zoom, with cadets and their vis-a-vis exchanging video, images, and text in real time. Small group videoconferencing - for example, one teacher or native speaker working 
with two or three cadets, evoked quite an intensive speaking experience. The conversations were recorded and reviewed later for self-evaluations, peer and teacher feedback.

The general level of formation of communicative competence by means of ICT is the main empirical indicator which proves the efficiency of the work carried out at the formative stage of the experiment. It reflects the overall impact of individual stages, methods and approaches on the formation of future officers' communicative competence. The results of forming communicative competence are presented in Table 3.

Table 3

The level of forming communicative competence by means of ICT before and after the formative stage

\begin{tabular}{|c|c|c|c|c|c|c|c|c|}
\hline \multirow{2}{*}{ Levels of evaluation } & \multicolumn{4}{|c|}{ Experimental group } & \multicolumn{4}{c|}{ Control group } \\
\cline { 2 - 10 } & \multicolumn{2}{|c|}{ Before } & \multicolumn{2}{c|}{ After } & \multicolumn{2}{c|}{ Before } & \multicolumn{2}{c|}{ After } \\
\cline { 2 - 10 } & Number & $\%$ & Number & $\%$ & Number & $\%$ & Number & $\%$ \\
\hline Creative & 21 & 18,10 & 31 & 26.72 & 23 & 19.01 & 24 & 19.83 \\
\hline Constructive & 62 & 54.31 & 74 & 62.94 & 66 & 53.72 & 68 & 55.38 \\
\hline Reproductive & 32 & 27.59 & 12 & 10.34 & 33 & 21.21 & 30 & 24.79 \\
\hline & 115 & 100 & 117 & 100 & 122 & 100 & 122 & 100 \\
\hline
\end{tabular}

In order to prove the reliability of the received results, a criterion of angular transformation by Fischer for percentage data after the formative stage was applied.

Table 4

\section{Calculation of the criterion of angular transformation by Fischer after the formative stage}

\begin{tabular}{|c|c|c|c|}
\hline Groups & $\begin{array}{c}\text { Creative and constructive } \\
\text { levels of communicative } \\
\text { competence }\end{array}$ & $\begin{array}{c}\text { Reproductive level of } \\
\text { communicative } \\
\text { competence }\end{array}$ & Total \\
\hline Experimental & $105(89.66 \%)$ & $11(10.34 \%)$ & 115 \\
\hline Control & $92(75.31 \%)$ & $30(24.69 \%)$ & 122 \\
\hline Total & 195 & 42 & 237 \\
\hline
\end{tabular}

Tabular values:

$$
\varphi_{1}(89.66 \%)=2.3767, \varphi_{2}(75.31 \%)=2.102
$$

Empirical value $\varphi^{*}:$

$$
\varphi_{\text {emp }}^{*}=(2.376-2.102) \cdot \sqrt{\frac{115 \cdot 122}{115+122}}=0.401 \cdot \sqrt{61.19}=2.89
$$

Critical values $\varphi_{c r}$ :

$$
\varphi_{c r}^{*} \leq 1.57(p \leq 0.04) \text { and } \varphi_{c r}^{*} \leq 2.28(p \leq 0.01)
$$

If $\varphi_{e m p}^{*}>\varphi_{c r}^{*}$, then the hypothesis $\mathrm{H}_{1}$ on the increase in the level of communicative competence in the experimental group in comparison with the results of the control group is statistically proven. The conducted statistical verification of the experimental results testifies to the reliability and validity of the changes obtained at the formative stage with the growth of the level of formation of communicative competence of future officers gained by means of information and communication technologies. This determines the effectiveness of the innovations introduced at the formative stage of the experiment. 


\section{CONCLUSIONS AND FURTHER RESEARCH PROSPECTS}

The fact that ICT support modern principles of learning and language acquisition is undoubtful. They help create learner-centered, interactive, well-designed, and flexible learning environment [15]. The study proves that using ICT is definitely instrumental in forming communicative competence of future army officers by providing powerful motivation, promoting their autonomy, creativeness and cognitive skills. The rationale behind integrating ICT into language classroom is giving cadets the ability to work with up-to-date and authentic sources, facilitating interaction, providing greater freedom and flexibility to learn at one's own pace and convenience. The experience of using technology to complement traditional English classes has proved to be positive and stimulating both for cadets and teachers, giving them real-life contact with, and exposure to, experiences of native speakers and enabled future officers to access and research required information worldwide. The availability and proper use of sources like CALL and LMS software, audio and video clips, images, animations, e-dictionaries, apps, PowerPoint presentations, etc. was found very motivating, as they support cadets practicing a language in a different way. It has been established that employing computer technology as a tool in language teaching increases cadets' confidence, professional preparedness, language proficiency and overall academic skills. In the light of the above-mentioned it can be concluded that developing cadets' communicative competence using various ICT is effective, as it yields tangible outcomes, conforms with the present-day requirements of the educational process and meets cadets' needs. Moreover, this approach can be used both in classroom and during self-study, providing more freedom and flexibility to learn at one's own pace and convenience.

As for the prospects for further research, our suggestion is that clear methodological guidelines as well as practical recommendations should be developed on how to have an impressive array of ICT tools fully incorporated into the foreign language learning process in order to facilitate a learning environment that will open new possibilities.

\section{REFERENCES (TRANSLATED AND TRANSLITERATED)}

[1] S. Hennessy, K. Ruthven, and S. Brindley, Teacher perspectives on integrating ICT into subject teaching: Commitment, constraints, caution and change, 2005. [Online]. Available: http://www.educ.cam.ac.uk/research/projects/istl/WP042.pdf. Accessed on: March 7, 2021. (in English).

[2] M. Yunus, N. Nordin, H. Salehi, C. H. Sun, and M. A. Embi, "Pros and cons of using ICT in teaching ESL reading and writing, International Education Studies, vol. 6, no. 7, 2013. (in English).

[3] V. Yu. Bykov, "Theoretical and methodological principles of creating and developing modern means and technologies of learning", Collection of scientific works marking 10 years of Pedagogical Sciences Academy existence, vol. 2, 2002. (in Ukrainian).

[4] R. S. Gurevych, I. A. Shakhina, and A. O. Podzygun, "Google classroom as an effective tool of smart learning and monitoring of students' knowledge in vocational schools", Information Technologies and Learning Tools, vol. 79, no. 5, 2020. (in English).

[5] M. I. Zhaldak, V. Yu. Bykov, and O. Yu. Burov, Theoretical and methodological principles of education imformatization and practical realization of information and communication technologies in the educational sphere in Ukraine. Kyiv: Komprynt, 2019. (in Ukrainian).

[6] I. Ye. Klak, and N. I. Yatseniuk, "Forming the prospective foreign language teachers' communicative competence by means of multimedia teaching technologies", Information Technologies and Learning Tools, vol. 76, no. 2, 2020. (in Ukrainian).

[7] A. Yu. Yurzhenko, "An e-course based on the LMS MOODLE to teach maritime English forprofessional purpose", Information Technologies and Learning Tools, vol. 71, no. 3, 2019. (in English).

[8] S. Hubackova and M. Ruzickova, "Experience in foreign language teaching with ICT support", Procedia Computer Science, Vol. 56, no 3, 2011. (in English).

[9] N. Y. Asabere, and S. E. Enguah, "Integration of expert systems in mobile learning", International Journal of Information and Communication Technology Research, vol. 2, no.1, 2012. (in English). 
[10] S. Livingstone, "Critical reflections on the benefits of ICT in education", Oxford Review of Education, vol. 38, no. 1, 2012. (in English).

[11] D. Çakici, "The use of ICT in teaching English as a foreign language", Participatory Educational Research, no 4, 2016. (in English).

[12] I. A. Vereitina, "Virtuality in educational environment", Higher education, no. 3, 2012. (in Ukrainian).

[13] D. H. Hymes, On Communicative Competence, Sociolinguistics. Harmondsworth: Penguin, 1972. (in English).

[14] B. H. Spitzberg and W. R. Cupach, Inter Personal Communication Competence. Beverly Hills, CA: Sage, 2012. (in English).

[15] B. Ghasemi and M. Hashemi, "ICT: New wave in English language learning/teaching", Procedia Computer Science, vol. 56, no 3, 2011. (in English).

\title{
ЗАСТОСУВАННЯ ІНФОРМАЦЙНО-КОМУНІКАЦИЙНИХ ТЕХНОЛОГІЙ ПРИ ФОРМУВАННІ ІНШОМОВНОЇ КОМПЕТЕНТНОСТІ МАЙБУТНІХ ОФІЦЕРІВ ЗБРОЙНИХ СИЛ УКРАЇНИ
}

\author{
Совгар Оксана Михайлівна \\ кандидат педагогічних наук, доцент кафедри іноземних мов та військового перекладу \\ Національна академія сухопутних військ імені гетьмана Петра Сагайдачного, м. Львів, Україна \\ ORCID ID 0000-0002-3101-7409 \\ okssov@yahoo.com
}

\begin{abstract}
Анотація. У статті наведено аналіз, теоретичне обгрунтування та результати емпіричної апробації використання інформаційно-комунікаційних технологій (IКT) 3 метою формування іншомовної комунікативної компетентності у майбутніх офіцерів Збройних Сил України. Надано огляд ІКТ та проілюстровано способи їх інтеграції в процес вивчення іноземної мови у військових закладах вищої освіти. 3 метою підтвердження доцільності та ефективності впровадження ІКТ у навчальний процес військових проведено педагогічний експеримент та описано його результати. Результатом експерименту було встановлено підвищення самооцінки, краще оволодіння комунікативними вміннями, зростання професійної підготовленості та загальних академічних навичок курсантів. Впровадження ІКТ також виявилось важливим для забезпечення потужної мотивації, впливаючи на ставлення курсантів до вивчення мови та сприяючи самостійності, творчості та розвитку пізнавальних навичок. Для майбутніх офіцерів можливість взаємодії та спілкування 3 носіями мови, колегами чи військовими експертами, залучення до міжнародних проєктів шляхом використання відеочатів і здійснення телефонних дзвінків виявилось особливо надихаючим та стимулюючим досвідом. Серед переваг інтеграції інформаційнокомунікаційних технологій було виявлено можливість обирати та пристосовувати матеріали та завдання для розвитку комунікативної компетентності залежно від стилю навчання окремих курсантів, у такий спосіб сприяючи індивідуалізації навчання. Було виявлено, що використання наочності, а саме зображень, відео, графіки та ілюстрацій, а також аудіо та відеоресурсів спонукало курсантів до більш активного говоріння та читання й полегшувало сприйняття текстів. Разом 3 технологіями курсанти отримали більший контроль над своїм навчанням і більше свободи для співпраці в аудиторії та поза нею.
\end{abstract}

Ключові слова: інформаційно-комунікаційні технології (IКТ); курсанти; іншомовна комунікативна компетентність; вивчення мови.

\section{ИСПОЛЬЗОВАНИЕ ИНФОРМАЦИОННО-КОММУНИКАЦИОННЫХ ТЕХНОЛОГИЙ ПРИ ФОРМИРОВАНИИ ИНОЯЗЫЧНОЙ КОММУНИКАТИВНОЙ КОМПЕТЕНТНОСТИ БУДУЩИХ ОФИЦЕРОВ ВООРУЖЕННЫХ СИЛ УКРАИНЫ}




\title{
Совгар Оксана Михайловна
}

кандидат педагогических наук, доцент кафедры иностранных языков и военного перевода Национальная академия сухопутных войск имени гетмана Петра Сагайдачного, г. Львов, Украина ORCID ID 0000-0002-3101-7409

okssov@yahoo.com

\begin{abstract}
Аннотация. В статье представлен анализ, теоретическое обоснование и результаты эмпирической апробации информационно-коммуникационных технологий (ИКТ), используемых в качестве инструмента, помогающего будущим офицерам Вооруженных Сил Украины овладеть иноязычной коммуникативной компетенцией. Представлен обзор различных ИКТ, используемых при обучении языкам; а также обоснована интеграция информационно-коммуникационных технологий в процесс обучения курсантов. Для проверки эффективности ИКТ в военной учебной среде был проведен педагогический эксперимент; описаны его результаты. Эксперимент доказал эффективность использования ИКТ в процессе изучения иностранного языка в высшем военном учебном заведении, что привело к повышению самооценки курсантов, уровня владения языком, профессиональной подготовки и общих академических навыков. Внедрение ИКТ также сыграло важную роль в обеспечении мощной мотивации, оказало влияние на отношение курсантов к изучению языка и способствовало автономии, творчеству и развитию когнитивных навыков. Для будущих офицеров возможность взаимодействия и реального контакта с носителями языка, коллегами или военными экспертами, а также участие в международных проектах путем использования видеочатов и видеозвонков оказалось особенно результативным. Среди сильных сторон интеграции информационно-коммуникационных технологий - способность выбирать и приспосабливать материалы и задания в зависимости от стиля обучения каждого курсанта. Использование наглядных пособий, таких как изображения, видео, инфографика, мультимедийные презентации мотивировало курсантов заниматься чтением, облегчая восприятие текстов, иллюстрированных изображениями, графикой, аудио и видео. Наряду с технологиями курсанты получили больший контроль над своим обучением и больше свободы для совместной работы в классе и вне класса.
\end{abstract}

Ключевые слова: информационно-коммуникационные технологии (ИКТ); курсанты; иноязычная коммуникативная компетенция; изучение языка.

\section{$(\mathrm{Cc}) \mathrm{BY}-\mathrm{NC}-\mathrm{SA}$}

This work is licensed under Creative Commons Attribution-NonCommercial-ShareAlike 4.0 International License. 